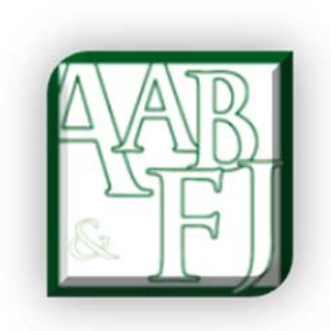

\title{
The Influence of IFRS Adoption on Corporate Transparency and Accountability: Evidence from New Zealand
}

\author{
Jude Edeigba $^{1}$ and Felix Amenkhienan ${ }^{2}$
}

\begin{abstract}
This study investigates the implications of the gap between International Financial Reporting Standards (IFRS) and New Zealand International Financial Reporting Standards (NZIFRS) on financial reporting transparency, accountability and corporate fraud. Content analysis of IFRS and NZIFRS was carried out to determine if there are differences between IFRS and NZIFRS. Four IFRS, namely IAS 12, IFRS 13, IFRS 15, IAS 17 and IFRS 16 were analysed on the basis of adoption concessions and Reduced Disclosure Regime (RDR) for tier 1 and 2 entities. The findings from these standards led to a review of the associated IFRS to further understand the implications of the standards on financial reporting transparency and decline in incidences of corporate fraud. We found that the difference between IFRS and NZIFRS lies in the financial reporting framework for tier 2 entities. However, we did not find a difference between IFRS and NZIFRS for entities in tier 1 but we identified a decline in incidences of corporate fraud after IFRS was adopted. We further identified the presence of information asymmetry for tier 2 which is capable of retaining Generally Accepted Accounting Principles (GAAPs). These differences may increase the incidence of corporate fraud among the entities in tier 2 of External Reporting Framework. This is due to an excessive concession from IFRS implementation in New Zealand.
\end{abstract}

JEL Classification: G34, G38, M48

Keywords: Corporate Fraud, IFRS, New Zealand, IAS 12, IFRS 13, IFRS 15, IAS 17, IFRS 16

${ }^{1}$ Corresponding Author, Department of Financial and Business Systems, Faculty of Agribusiness and Commerce, Lincoln University, New Zealand.

${ }^{2}$ Department of Accounting, Finance and Business Law, Box 6951, Radford University, Virginia, USA. 


\section{Introduction}

Adoption of IFRS has continued to grow since 2005 following the European Union implementation of IFRS for listed entities in the EU jurisdictions (Brüggemann, Hitz, \& Sellhorn, 2013). One of the factors enhancing the implementation of IFRS is the general perception that IFRS enhances accounting information comparability, relevance, reliability, transparency and uniform measurement and valuation of accounting assets and liabilities and wider scope of acceptance around the world (White \& Ryan, 2007).

The need for greater accounting information quality and reliability is often referred to by accounting regulators, practitioners and accounting scholars as a reason for IFRS implementation (Ali, 2005; Khan, Anderson, Warsame, \& Wright, 2015). Following EU announcement of IFRS adoption, many other countries such as Australia and New Zealand considered IFRS as alternative accounting standards for financial reporting (Zijl \& Bradbury, 2006). The overall driver of IFRS implementation in many countries including New Zealand is the quest for financial statements transparency and accountability by entities.

Implementation of IFRS in New Zealand is different from the experience in most countries in four ways. First, the entities are divided into tiers based on revenues and assets. This means that both publicly accountable and non-publicly accountable entities as well as large entities were required to comply with IFRS. Second, entities in New Zealand are divided into four tiers with two tiers complying with IFRS. Third, IFRS issued by International Accounting Standards Board (IASB) are modified into Reduced Disclosure Regime (RDR) for Tier 2 entities. Four, IFRS are not applicable for small and medium enterprises.

The four tiers set a benchmark for transparency and accountability according to entity's size. However, in the past years, stakeholders have seen the collapse of large firms such as Enron, WorldCom and Arthur Andersen (Griffin, Lont, \& Sun, 2009). The enactment of the SarbanesOxley Act of 2002 in the United States (US) was part of the move towards greater transparency under section 302 (Cook, Huston, \& Omer, 2008). Some accounting practitioners are of the views that the move towards greater transparency is an overarching measure of corporate accountability and business sustainability (Khan et al., 2015; Schaltegger \& Burritt, 2010).

Different from Sarbanes-Oxley Act of 2002 in accounting regulation, IFRS have been widely implemented as another measure of addressing corporate fraud. The strict measures to increase accountability have some consequences to preparers of financial statements in terms of the cost of complying with the reporting requirements (Salman \& Carson, 2009; Sunder, 2009). However, a handful studies have investigated the success of IFRS in reducing cases of corporate fraud and the implications of different versions of IFRS. This study focuses on examining these implications to New Zealand IFRS compliance status and also implications for corporate accountability.

The accounting system in New Zealand was reviewed in the study. This is followed by a discussion of NZIFRS and IFRS. The methodology applied in the study was presented following the comparison of IFRS. Gernon, Purvis, and Diamond (1990) recommended evaluative approach was applied in the study. This is followed by analysis of IFRS and fraud occurrences 
following IFRS implementation. Financial reporting offences from 2004 to 2015 were discussed. The section thereafter presented the findings followed by conclusion and recommendations.

\section{Accounting System in New Zealand}

The accounting system in New Zealand is divided into four categories namely tier 1, tier 2, tier 3, and tier 4 (see Figure 1). Each of these tiers consists of entities required to comply with the accountings standards underpinning financial transactions related to the entities' tier.

In determining the tier associated with an entity, certain characteristics have to be met. For entities in tier 1, the entity must be publicly accountable. This is consistent with IASB requirements for entities complying with the IFRS for publicly accountable companies. Entities in tier 2 are not publicly accountable. This includes for-profit entities considered large by assets and revenues and small entities considered small by revenues, assets, liabilities and employees.

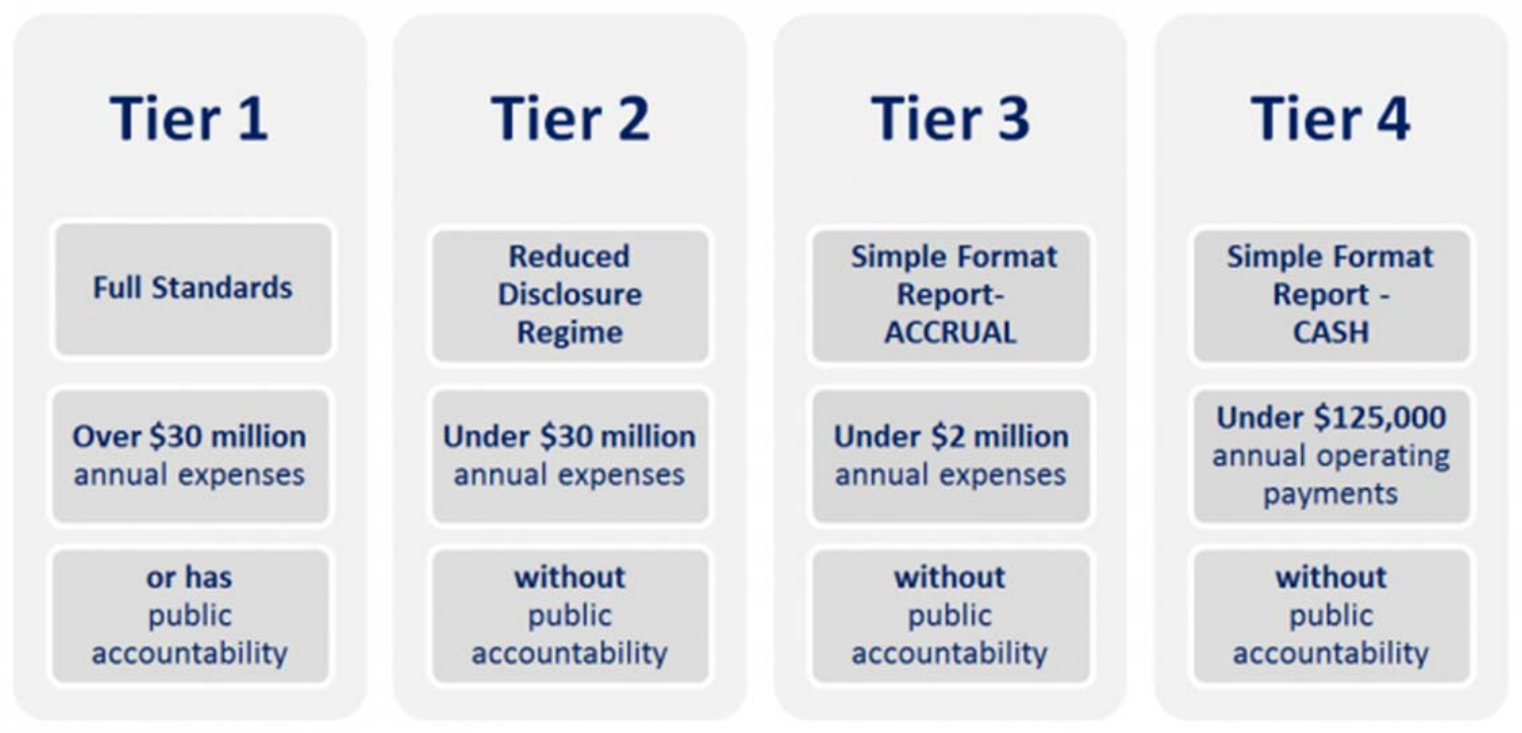

Figure 1. A Framework for the Determination of Entities Financial Reporting Requirements Sources: Adapted from The External Reporting Board of New Zealand.

Large entities are required to comply with a different version of IFRS. Accounting requirements applicable to entities in tier 2 are those provided under the RDR. They include measurement and disclosure concessions. Entities with less than NZ\$2,000, 000 expenses per annum are considered small. Therefore, the tier 3 reporting requirements apply. These entities in the tier 3 are known as Public Benefit Entities (PBEs). These accounting standards for tier $1-3$ are mainly accrual basis reporting. The entities allowed by law to apply the cash accounting reporting system are classified as tier 4 entities.

The motive towards this tier system is to ensure practicality and accountability among entities at different levels. Entities in tier 1 are required to comply with the New Zealand version of IFRS which are believed to conform to IFRS (External Reporting Board of New Zealand, 2016). In examining the gap between NZIFRS and IFRS, we focus on entities in tiers 1 and 2. 


\subsection{Comparative Analysis of IFRS and NZIFRS}

International Financial Reporting Standards are developed to reflect every aspect of business transactions in the accounting principle of substance over form. The breadth of IFRS contributes to the robustness that is often preferred by regulators and practitioners. However, previous research found a lack of practicality in financial reporting following IFRS adoption (Misirlioglu, Tucker, \& Yükseltürk, 2013), indicating the need for critical evaluation of IFRS to meet the needs of users of financial statements. During the implementation stage of IFRS in New Zealand, White and Ryan (2007) and The New Zealand Treasury (2007) believed there is an insignificant difference between IFRS and New Zealand GAAPs with the exception of sector neutrality. However, earlier study found that the application of IFRS to a financial statement is mutually exclusive from the application of New Zealand GAAPs. This is evident in the illustration in Deloitte (2005). The mutual exclusivity is further examined in this study.

\section{Methodology}

The perceived financial reporting transparency derived from IFRS adoption is considered by the Department of Economics in New Zealand as a reason for IFRS adoption (Borker, 2013; Samujh, 2007). It is not clear how the IFRS adoption enhances financial statements transparency across all entities. Therefore, a content analysis is applied in the study to understand the impact of IFRS adoption on financial reporting transparency and accountability.

From the IASB standards, IFRS 1 and NZIFRS 1 require a preparation of balance sheet, income statement, statement of changes in equity and cash flow statements. Optional consideration is given to entities to include contributions or distributions from or to owners in the statement of changes in equity or presents such information in a note to the account. The IFRS system involves series of measurements and disclosures of accounting items. Accounting fraud are more likely to occur from measurement, revenue recognition and income tax estimation (Artikis \& Doukakis, 2010; Dechow \& Dichev, 2002; DeFond \& Jiambalvo, 1991). Therefore, IFRS related to the measurement of accounting values (IFRS 13), recognition of income and expenses (IFRS 15, IFRS 16 and IAS 17), and IAS 12 for income tax accounting requirements were examined against the NZIFRS versions to identify the differences between IFRS and NZIFRS. The outcomes are then used to justify how the XRB IFRS adoption strategy could impact on financial reporting transparency in New Zealand.

In comparability analysis of conformity with IFRS Gernon, Purvis, and Diamond (1990) recommended such analysis could be applied on the basis of:

1. IAS adopted as national standards

2. IAS used as the basis for a national requirement

3. National requirements conform in all material respects with IAS

4. National practice generally conforms to IAS

5. National requirements do not conform to IAS

6. National practice does not generally conform to IAS

We applied 2 to 6 of the recommended approach to identify the New Zealand stance on IFRS adoption and the rationality for concessions. International Accounting Standards as national standards is a known fact in the case of New Zealand, therefore this step is excluded from the 
analysis. From Gernon, Purvis, and Diamond (1990), New Zealand accounting system was assumed to be strongly correlated with IFRS prior to the data analysis (content analysis). The methodology applied in this study is consistent with Perumpral, Evans, Agarwal, and Amenkhienan (2009).

To investigate the effects of IFRS on accountability and transparency, we reviewed the corporate fraud cases in New Zealand from the data obtained under the Official Information Request Act 1982 from the New Zealand Ministry of Justice. Comprehensive list of all accounting standards applicable to tier 1 and 2 entities in New Zealand was obtained from XRB database. Similarly, IFRS were obtained from IASB database.

The analysis includes an examination of the XRB historical amendments of each standard in comparison with IASB requirements. Each standard was content analysed within the indicators of amendments reported by XRB. To examine the effectiveness of IFRS adoption on corporate fraud control, we observed the data of financial reporting court charges and convictions from 2004 - 2015. Data for financial offence charges and conviction for New Zealand entities was only available between $2004-2015$.

\section{International Financial Reporting Standards and fraud occurrences}

One of the areas in which entities are likely to engage in financial reporting compromise ${ }^{3}$ is revenue recognition. It comprises of tangible or intangible assets and liabilities that increase financial performance in book value whilst the actual accounting value is unknown until the conversion to cash or cheque is completed. Managers may benefit from such practice particularly if share-based compensation is involved which is ironically translated into cash by way of future sales. The measurement and disclosure options in IFRS revenue recognition are flexible, given that preparers of financial statements could apply the accounting standards towards their individual advantage. This makes the measurement and disclosure options in IFRS fraud riskier when converted to national adoption. Risk implications of modified IFRS to meet national financial reporting needs are discussed next.

\subsection{International Financial Reporting Standards 15 (IFRS 15): Contract Revenue}

Recognition of income from contracts is determined from the accounting principles in NZIFRS 15. Such contracts could be written, unwritten or both. We identified a significant difference between IASB and XRB versions of IFRS 15 for New Zealand entities. The adoption and adaptation of IFRS 15 are similar to NZIFRS 15 for tier 1 entities and different for tier 2 entities. Changes to IFRS 15 consists of deleted and additional measurements and disclosure requirements for some entities.

The changes to IFRS 15 reflect the substance over form principle of accounting practice in the New Zealand IFRS adoption. For example, paragraph 4.2 of NZIFRS is amended and different from IFRS. The XRB changes to paragraph 4.2 of IFRS 15 defined the entities eligible to comply with IFRS 15. For example, tier 2 entities are excluded from complying with IFRS. Tier 2

\footnotetext{
3“External expectations conflict (e.g., shareholder demands for increased efficiency versus public pressures for the allocation of corporate resources to a social cause), organizations' interests may be served most effectively by obtaining an acceptable compromise on competing objectives and expectations” (Oliver, 1991, p. 153). In most cases, organisations would apply tactics to partially comply with some constituents.
} 
entities could voluntarily comply with IFRS 15 requirements and maintain the compliance consistently in its application. For IFRS, there is a complete absence of paragraph 4.1 and 4.2. The implication of this difference indicates that in some countries, all the applicable IFRS 15 requirements could be complied with whilst New Zealand entities exclude IFRS 15 requirements exempted under paragraph 4.2. This will lead to differences between New Zealand and international financial statements.

International Financial Reporting Standards permit entities complying with IFRS 15 to comply with paragraph 115. On the other hand, XRB mandates compliance with paragraph 115 for entities in tier 1. Paragraph 115 of NZIFRS 15 requires entities to disclose sufficient information to support users of financial statements. Such information is needed to understand the relationship between the disclosure of disaggregated revenue (in accordance with paragraph 114) and details of revenue disclosed for each reputable segment if IFRS 8 operating segment is applied.

First, the implications of the changes to paragraph 115 of NZIFRS 15 is the lack of comparability of financial statements if an investor compares a New Zealand entity with an international entity with similar investment opportunities. This causes difficulties in the interpretation of the financial performance of both entities. Secondly, accountants in New Zealand may have an in-depth understanding of the rationale leading to the difference between tier 1 and tier 2 NZIFRS 15 requirements. However, international accountants such as Nigerian entities that adopted IFRS without amendments would have a limited understanding of the difference. Therefore, comparability of international accounting standards harmonisation is limited by the scope of compliance.

The exclusion of paragraph 115 of IFRS 15 indicates XRB's desire for financial reporting relevance and practicality in the business locale. Paragraph 115 provides increased disclosure with evidence from Nichols, Street, and Cereola (2012) investigation of European blue chips ${ }^{4}$.

Entities in tier 2 are further excluded from paragraph 116 B and paragraph C. Therefore, it undermines disclosure of revenues recognised in the operating period that were included in the contract liabilities at the beginning of the trading year and disclosure of changes in transaction cost (para C) for tier 2 entities. However, this paragraph applies to entities in tier 1 as required by IFRS.

The XRB excludes entities in tier 2 from complying with the entire disclosure requirements in paragraph 117 and 118 and from subparagraph A to subparagraph E. It can be noted that paragraph 117 has the tendency to detect systemic fraud that would have resulted in unethical accounting practice of recognising revenue from performed or unperformed contractual obligations against payment date and the effects of such recognition on assets or liabilities balances.

Further to the information gap resulting from IFRS amendment, exclusion of paragraph 118 of NZIFRS 15 provides discretional opportunities for entities in tier 2 not to disclose information about changes in the contract assets and contract liabilities. This information could support investors' decisions who depend on such changes for withdrawal of capital from the business or

\footnotetext{
${ }^{4}$ Entities in the top tier index of 14 European stock exchanges complying with IFRS
} 
increase in investment in the same entity or sector. Entities could also apply this regulatory gap to management earnings against the ethic of accounting practice. Noncompliance with NZIFRS 15 paragraph 118 indicates that entities with similar transactions are likely to conceal information related to:

(a) changes due to business combinations

(b) cumulative adjustments to revenue that affect the corresponding contract asset or contract liabilities, including adjustments arising from a change in the measure of progress, a change in an estimate of the transaction price (including any changes in the assessment of whether an estimate of variable consideration is constrained) or a change in contract terms and conditions;

(c) impairment of a contract asset;

(d) a change in the timeframe for a right to consideration to become unconditional (i.e. for a contract asset to be reclassified to a receivable); and

(e) a change in the timeframe for a performance obligation to be satisfied (i.e. for the recognition of revenue arising from contract liabilities).

Concession available to entities in tier 2 excludes the entities from complying with the disclosure of amount related to an unsatisfied or partially unsatisfied contract performance (paragraph 120). The implication of this concession suggests that entities not complying with paragraph 120 of NZIFRS 15 could use the contract amount to increase the reported profit. In reality, the accounting item contributing to the profit has a contractual obligation that has not been performed and could rather have been accounted for as liabilities than profit.

New Zealand International Financial Reporting Standard 15 concession does not give non-listed entities the right to discretionally comply with paragraph 120 practical expedient accounting policy, if either subparagraph A or B are met under paragraph 121. The concession creates information asymmetry if a tier 2 entity has some elements of practical expedient in their financial transactions. The concession gives tier 2 entities the right to omit qualitative information required in paragraph 122. That could be useful to users of financial statements and as an explanation of why the methods used provided a faithful depiction of the transfer of goods or services (paragraph $124 \mathrm{~b}$ ).

The concession system under XRB further reduced transparency for entities in tier 2 by the exclusion of paragraph 126 of the NZIFRS 15 which requires disclose of information about the methods, inputs and assumptions used for determining the transaction price, assessing whether an estimate of variables consideration is constrained and allocation of the transaction price.

Concession for paragraph 127(b) means that tier 2 entities are not required to present the costs incurred to obtain or fulfil a contract with a customer in accordance with paragraph 91 or 95 of NZIFRS 15. This concession can lead to unfair contract bidding if the entities in tier 2 considered the meaning that may be assigned to the expenditure for securing contracts, particularly initial cost prior to contract approval. A further limitation to the transparency that could have been obtained from complying with NZIFRS 15 is observed in paragraph 128 subparagraph A. It excludes tier 2 entities from complying with the disclosure of assets 
recognised from the costs incurred to fulfil a contract with a customer in accordance with paragraph 91 or 95.

New Zealand International Financial Reporting Standard 15 is further elongated by RDR 128.1. It requires Tier 2 entities to disclose the closing balances of assets recognised from the costs incurred to obtain or fulfil a contract with a customer in accordance with paragraph 91 or 95. A concession is available for tier 2 entities to discretionally elect to apply the concessions in paragraph 115, 116(b) - (c), 117 - 118, 120 - 122, 124 (b), 126, 127(a) and 128(a). Additionally, RDR 128.1 of NZIFRS 15 issued in December 2014 applies when revenue from contracts accounting requirements become mandatory from January 2018.

\subsection{International Financial Reporting Standards 13: Fair Value Measurement}

Paragraph 52 of IFRS 13 is amended in NZIFRS 13. It highlights the options for reporting income related to contracts under NZIFRS 13.

For IFRS 13, entities could elect to comply with IFRS 13 with the option of applying IFRS 9 or IAS 39 where IFRS 9 has not been adopted. Information asymmetry may occur if international entities comply with IFRS 13 differently from NZIFRS 13 where IFRS 9 applies. There are significant differences when IFRS 9 and IAS 39 are applied to financial statements. Such differences would be observed between countries complying with IFRS 13 that have not adopted IFRS 9 or elected to comply with IAS 39 as the option provided by IASB.

By applying IAS 39 reclassification of financial assets previously measured at fair to amortised costs, a bank, for example, can avoid fair value losses and consequently increase its income and declared capital during economic recessions. The implication of the reclassification of related assets increases the complexities in analyst forecast thereby contributing to inaccuracy in forecasted earnings predictability (Lim, Lim, \& Lobo, 2013).

The main principle of IFRS 9 focuses on financial assets similar to IAS 39. However, IFRS 9 requires measurement of a financial asset at amortised cost or fair value. Decisions on applying one of the two options depend on the preparers of financial statements. This could further depend on the nature of the financial instrument and management system. There is no restriction on which method to use in this case. However, this method has the likelihood of facilitating the incidence of fraud in some organisations, particularly among fund managers. It is believed the introduction of IFRS 9 was to remedy the criticisms of IAS 39 and to enhance investors' confidence in financial information (Onali \& Ginesti, 2014). However, this is not the case when both or any of the standards is applied to financial statements.

The dichotomy of stakeholders' reactions to IAS 39 and IFRS 9 is an evidence of the likelihood of misleading materiality if the two standards are applied in measuring financial instruments.

Paragraph NZ C1.1 narrowed the scope of IFRS 13 for entities in tier 1 and 2. The paragraph stipulates disclosure concessions for tier 2 entities. This amendment will lead to a significant difference between financial statements from New Zealand and those from other countries with similar assets measured at fair value. The amendment of NZIFRS 13 paragraph NZ C4 does not indicate a significant difference between IASB and XRB. 


\subsection{International Financial Reporting Standards (NZ IAS 12): Income Taxes}

Generally, for the purpose of taxation, two accounts are maintained. One is accounting profit account and the second is the tax account. The rationale between this accounting for taxation is the differences that exist between tax legislation and accounting regulations. Consequently, differences would occur between accounting profit and tax profit due to differences in measurement. Tax profits are likely to occur from taxable activities when taxable income exceed taxable expenses. On the other hand, accounting profit occurs when income from business activities exceeds related expenses. The activities leading to accounting and tax profit are mostly accruals and historical business activities. Therefore, measurement and recognition rules from accounting regulators apply to accounting profit whilst measurement and recognition rules for tax profit are regulated by the tax authority.

From NZIAS 12 paragraph $81(\mathrm{ab})$, tier 2 entities are exempted from disclosing "supplies goods or services within a clearly identifiable operating cycle, separate classification of current and non-current assets and liabilities in the statement of financial position. These exemptions are meant to provide useful information by distinguishing the net assets that are continuously circulating as working capital from those used in the entity's long-term operations. The concession in IAS 12 highlights assets that are expected to be realised within the current operating cycle, and liabilities that are due for settlement within the same period" as required in NZIAS 1 paragraph 62 (External Reporting Board of New Zealand, 2007, p. 36). This disclosure concession reduces information contents for tier 2 entities and consequently increases investment risks and lack of transparency.

The New Zealand version of IAS 12 is similar to IAS 12 for tier 1 entities in terms of financial statements preparation requirements but different for tier 2 entities. The differences are as follows:

1. The basic principle associated with IAS 12 is to determine the income tax and make necessary payment as soon as possible with some elements of professional judgement. A significant difference can be observed from New Zealand Statements of Standard Accounting Practice 12 (SSAP 12) and IAS 12.

2. The SSAP 12 for measurement and disclosure of income tax could be satisfied using either income statements or balance sheet approach for measuring deferred tax. In contrast, the income statement approach is abolished in IAS 12 which is considered as a welcome development since the controversial debate about the use of income statement approach. However, tax components of entities in tier 2 consist of similar requirements in SSAP 12. This is again different from IAS 12 income taxes requirements.

3. Exemption of tier 2 entities from complying with certain requirements under NZIAS12 suggests that the scope of IAS 12 disclosure requirements has been modified. This will generally reduce transparency in financial statements of non-listed entities for tax expenses.

4. Generally, the impact of IAS 12 is the reporting requirement which has a broader coverage of economic activities that contribute to deferred tax in a widened form than the income statement approach practised before IAS 12 was implemented and subsequently amended. 
Development of RDR as a concession for reporting tier 2 entities indicates a lack of in-depth financial reporting for entities considered as non-listed but large by assets and revenues. This provides opportunities for preparers of financial statements to exclude information that will be useful in supporting the business transaction with the entities. From the series of exceptions for tier 2 entities, the income approach becomes practicable and could be used for creative accounting as against true financial position of the entities.

\subsection{International Financial Reporting Standards (IAS 17 and IFRS 16): Leases}

One of the accounting standards that most specifically requires professional judgement is the IAS 17, accounting for leases. This standard has led to unethical and doubtful financial reporting since 1982 when it was first issued. International Accounting Standard 17 is the first standards applying the principles of substance over form. Some way or the other, entities have misinterpreted its application. That is to say that some entities have deliberately or in error applied IAS 17 incorrectly which results in off balance sheet financing. Such accounting practice is unethical or illegal in some jurisdictions. In some cases, incorrect application of IAS 17 could be interpreted as potential elements of corporate fraud by withholding important financial information that supports users of financial statements decisions.

The main principle behind these standards is the determination of what constitutes a lease and what type of leases exist in accounting transactions.

From IAS 17 requirements, a lease can be finance lease or operating lease. Finance lease occurs if one or all of the following are met:

1. The lessee takes ownership of the underlining asset at the end of the lease period

2. From the beginning of the lease, an insignificant difference between present value of minimum lease payments and fair value exists. In other words, there is closeness between the minimum lease payment and fair value of the lease assets

3. The nature of the assets specifically allows the lessee to use the asset without major modification

4. The major part of the economy life of the asset is leased. That means the majority of the economic life of the assets is leased, and

5. An option exists to purchase the asset by the lessee for a price lower than its fair value at the end of the lease term

Financing lease usually comes with a payment of principal plus interests. The technicality involved in lease accounting is the application of interest rate implicit. This means an internal rate of return is used in calculating the interest rather than a simple division of the principal and the accrued interests by the number of years. In addition, caution is required in classifying the portion of payable lease amount as current or long-term liabilities. In some cases, the impacts of changes in implied interests are sometimes not reported nor accurately classified as current or long-term liabilities by entities.

In contrast with financing lease, operating lease occurs if the lessee is obliged to pay the lessor regular rents for the asset over a period of term. The rental is recognisable in the income statement as expenses and can be accounted for using the straight line method. Critics of lease accounting are concerned about the methodological approach for accounting for leases under 
IAS 17. International Accounting Standards Board has made some changes to IAS 17. This change is effective in January 2019 with a switch from IAS 17 to IFRS 16 leases.

International Accounting Standard 17 does not foster transparency. Its application is susceptible to fraud. First, the disclosure and measurement requirements that support the substance of financing leases can be misinterpreted by financial statements preparers. Second, compliance or application of changes in interest rate can be delayed for existing leases if there is a significant impact on the financial performance during the annual reporting date. This is more likely when changes in interest rate are introduced close to the end of the trading year. For example, in the case of changes in interest rate, banks may be hesitant to pass the rate to lessees if no law requires them to pass the changes on to lessees. Third, the volatility in the macro economy and analyst inaccuracy in predicting the earnings could mislead users of financial statements about the entities' solvency in the long run. This factor is related to the inadequacy of a lessee's lease expense disclosure. However, liquidity can be used in the short term if there is an absence of offbalance sheet financing.

The lack of transparency associated with IAS 17 has greater capability to encourage material misstatement in a form of corporate fraud. This is more likely if further exemption is provided for entities in tier 2 in a form of RDR. Although, IAS 17 has been replaced with IFRS 16. This came following IASB's confirmation of a lack of economic representativeness of lease expense disclosures in financial statements using IAS 17. Information inadequacy in financial statements related to operating lease is one of the motivating factors leading to the issuance of IFRS 16. It is expected that the measurement and disclosure requirements in IFRS 16 would lead to greater disclosure and consequently, more transparent financial information.

Greater contextual similarities between IASB and XRB versions of IFRS 16 were observed from the disclosure and measurement requirements. Interestingly, there is an absence of RDR for tier 2 entities in IFRS 16 as opposed to the series of amendments to IAS 17. This is a positive development for New Zealand financial reporting regulation.

New Zealand IFRS 16 consists of unrelated amendments to other IFRS. It is not clear whether inclusion of other standards in IFRS simultaneously applies to the entities for lease accounting or updates on other IFRS. However, XRB concessions for other accounting standards continued to produce IFRS that are enforced differently for tier 1 and 2 entities. This could lead to possible financial information misrepresentation due to the exemptions for tier 2 entities.

\subsection{Corporate Financial Reporting Offences in New Zealand}

From the official information request, the level of corporate fraud prior to IFRS adoption is higher than post IFRS adoption (see Table 1). This represents a significant drop in corporate financial reporting charges and convictions from 2007 to 2015. The need for transparency in corporate accountability is further aligned with the increases in the rate of corporate accounting fraud and incidents of tax fraud.

In 2007, following IFRS adoption in New Zealand, the number of entities charged and convicted is lower than it was for 2004 to 2006. From 2008 to 2015 only a handful of entities were charged 
for financial reporting offences or crime. Reduction in the occurrences of financial offences shows the effectiveness of IFRS application. Therefore, IFRS serve as preventative measures to enhance financial reporting transparency in New Zealand.

The concessions for entities in tier 2 indicate that international financial reporting standards may be compromised. This is more likely if entities in tier 2 have no legal requirements to file annual financial statements with the financial market authority or an oversight risk management authority.

Table 1. Number of Charges Under the Financial Act 1993 and the Financial Transaction Reporting Act 1996 against Corporations, by charge outcome

\begin{tabular}{|c|c|c|c|c|c|c|c|c|c|c|c|c|c|}
\hline Offence Description & $\begin{array}{l}\text { Charge } \\
\text { outcome }\end{array}$ & 2004 & 2005 & 2006 & 2007 & 2008 & 2009 & 2010 & 2011 & 2012 & 2013 & 2014 & 2015 \\
\hline \multirow{2}{*}{$\begin{array}{l}\text { Breach Financial } \\
\text { Reporting Act } 1993\end{array}$} & Convicted & 0 & 0 & 480 & 0 & 0 & 0 & 0 & 0 & 0 & 0 & 0 & 0 \\
\hline & Not Proved & 0 & 0 & 186 & 0 & 0 & 0 & 0 & 0 & 0 & 0 & 0 & 0 \\
\hline \multirow[t]{2}{*}{ Failure to Keep Records } & Convicted & 0 & 0 & 1 & 18 & 0 & 0 & 0 & 0 & 0 & 0 & 0 & 0 \\
\hline & Not Proved & 0 & 5 & 1 & 0 & 0 & 0 & 0 & 0 & 0 & 0 & 0 & 0 \\
\hline \multirow{2}{*}{$\begin{array}{l}\text { Failure to Report } \\
\text { Suspicious Transaction }\end{array}$} & Convicted & 0 & 0 & 0 & 22 & 0 & 0 & 0 & 0 & 0 & 0 & 0 & 0 \\
\hline & Not Proved & 0 & 0 & 1 & 0 & 0 & 0 & 0 & 0 & 0 & 0 & 0 & 0 \\
\hline \multirow{2}{*}{$\begin{array}{l}\text { Failure to } \\
\text { Identity }\end{array}$} & Convicted & 10 & 5 & 0 & 0 & 0 & 0 & 0 & 0 & 0 & 0 & 0 & 0 \\
\hline & Not Proved & 0 & 0 & 3 & 0 & 0 & 0 & 0 & 0 & 0 & 0 & 0 & 0 \\
\hline $\begin{array}{l}\text { Make False / } \\
\text { Misleading Cash Report }\end{array}$ & Not Proved & 0 & 0 & 0 & 0 & 0 & 0 & 0 & 1 & 0 & 0 & 0 & 0 \\
\hline $\begin{array}{l}\text { Wilful Obstruction of a } \\
\text { Customer Officer }\end{array}$ & Convicted & 0 & 0 & 0 & 0 & 0 & 0 & 0 & 3 & 0 & 0 & 0 & 0 \\
\hline Total & & 10 & 10 & 672 & 40 & 0 & 0 & 0 & 4 & 0 & 0 & 0 & 0 \\
\hline
\end{tabular}

The reduction in financial reporting offences could be attributed to greater financial reporting transparency that exists in IFRS requirements and the limited chances for acquiescence, compromise, avoidance and manipulation of accounting items when enforced (Oliver, 1991). The reduction in the occurrence of charges and convictions associated with financial reporting could also be due to awareness by preparers of financial statements about the regulatory deterrence.

Table 2. Number of Corporations Charged under the Financial Reporting Act 1993 and the Financial Transaction Reporting Act 1996, by most serious charge

\begin{tabular}{|c|c|c|c|c|c|c|c|c|c|c|c|c|c|}
\hline Outcome & & 2004 & 2005 & 2006 & 2007 & 2008 & 2009 & 2010 & 2011 & 2012 & 2013 & 2014 & 2015 \\
\hline & Convicted & 1 & 1 & 34 & 1 & 0 & 0 & 0 & 1 & 0 & 0 & 0 & 0 \\
\hline & Not Proved & 0 & 0 & 1 & 0 & 0 & 0 & 0 & 0 & 0 & 0 & 0 & 0 \\
\hline Total & & 1 & 1 & 35 & 1 & 0 & 0 & 0 & 1 & 0 & 0 & 0 & 0 \\
\hline
\end{tabular}

Note: There are no recorded charges against corporations for the relevant offence codes prior to 2004 


\section{Findings}

The financial reporting requirements for IFRS and NZIFRS are similar for entities in tier 1 . New Zealand IFRS for tier 2 entities is significantly different from the IFRS issued by IASB, with the exception of IFRS 16 issued on $11^{\text {th }}$ February 2016.

Reasons for the differences include measurements and disclosures concessions in NZIFRS. Entities in tier 2 are expected to provide limited business financial activities information under the RDR. The New Zealand adoption approach is likely to lead to incomparable financial statements between local and international entities. Further, RDR could lead to corporate fraud if important information that would negatively influence investors' decisions are not disclosed.

The introduction of RDR indicates financial statements transparency is undermined in the NZIFRS accounting regime. However, NZIFRS financial reporting requirements for tier 1 entities have greater transparency than NZ GAAPs. This is evident from the indirect and direct corporate fraud cases associated with financial reporting under the Financial Reporting Act of 1993 and Financial Transaction Act of 1996.

\subsection{Implication of the Studies}

As a result of the differences between NZIFRS and IFRS, financial statements from entities in tier 2 are expected to be different from those of international entities. It implies that the principle of comparability of financial statements which underpins IASB is absent for New Zealand tier 2 entities. Consequently, a restatement of tier 2 entities' financial statements will be required when making international financial transaction decisions.

The findings indicate that the purpose of IFRS as global accounting standards is not met for entities in tier 2. This phenomenon is common among other IFRS jurisdictions such as the EU, Canada and Australia where IFRS apply to entities listed on the stock exchange or a specified board of exchange.

However, the XRB strategy for IFRS adoption through its financial reporting framework provides some benefits in two ways. First, the perception of the cost of financial statements production is reduced for tier 2 . Second, the practicality rationale of financial reporting for the preparers of financial statements exists for tier 2. This ensures that financial reporting for nonlarge entities is practically prepared to meet preparers' needs than legal requirement compliance that targets users of financial statements.

On the other hand, perceived information adequacy which is a factor in transparency is not common in the financial reporting requirements for tier 2 entities. Therefore, users of financial statements are likely to have limited information about the financial transactions of entities in tier 2 based on financial statements. Concessions in financial reporting could be explored for aggressive financial performance reporting, thereby providing materially misstated financial statements. Foreign investors could consider investments in non-large entities as costly during the initial stages of investment decision. This is more likely when non-listed entities' financial statements are to be restated to IFRS for decision support. 


\section{Conclusion}

The purpose of IFRS development is to eliminate differences in financial reporting through adaption or adoption of its financial reporting requirements. However, different versions of IFRS exist around the world. The variation in IFRS is a result of contextualisation to meet local accounting information for businesses. It implies a lack of harmony between national and international accounting standards (Pran, 2006). New Zealand is one of the actively participating countries in developing global accounting standards, particularly the International Public Sector Accounting Standards. However, the reporting requirements for entities in tier 2 are different from IFRS. The motive for the variation between IFRS and NZIFRS for tier 2 entities is associated with an effort to streamline contents of financial statements for non-listed entities. The implication is that transparency is unlikely for tier 2 entities if limited information is provided to stakeholders under the concessional accounting measurement and disclosure approaches. We also conclude that preparers of financial statements could apply measurement and disclosure concessions to aggressive accounting thereby increasing the risk in investment in non-listed entities. The study concludes that entities in tier 2 should be required to comply with IFRS similar to entities in tier 1 . Our recommendation should give all investable entities the opportunity to demonstrate the transparency attributes of the New Zealand corporate practice.

It is to be noted that our study focuses on a handful of IFRS and IAS that have been adopted by the accounting body in New Zealand. Our interpretation in this study may not be equally applicable in countries where IFRS are adopted with a different approach.

\section{References}

Ali, M. J. (2005). A Synthesis of Empirical Research on International Accounting Harmonization and Compliance with International Financial Reporting Standards. Journal of Accounting literature, 24, 1-52.

Artikis, G. P., \& Doukakis, L. C. (2010). The persistence of earnings and earnings components after the adoption of IFRS. Managerial Finance, 36(11), 969-980. https://doi.org/10.1108/03074351011081286

Borker, D. R. (2013). Is There A Favorable Cultural Profile For IFRS?: An Examination And Extension Of Gray's Accounting Value Hypotheses. International Business \& Economics Research Journal (IBER), 12(2), 167-178. https://doi.org/10.19030/iber.v12i2.7629

Brüggemann, U., Hitz, J.-M., \& Sellhorn, T. (2013). Intended and unintended consequences of mandatory IFRS adoption: A review of extant evidence and suggestions for future research. European Accounting Review, 22(1), 1-37. https://doi.org/10.1080/09638180.2012.718487

Cook, K. A., Huston, G. R., \& Omer, T. C. (2008). Earnings Management through Effective Tax Rates: The Effects of Tax-Planning Investment and the Sarbanes-Oxley Act of 2002. Contemporary Accounting Research, 25(2), 447-471. https://doi.org/10.1506/car.25.2.6

Dechow, P. M., \& Dichev, I. D. (2002). The quality of accruals and earnings: The role of accrual estimation errors. The Accounting Review, 77(s-1), 35-59. https://doi.org/10.2308/accr.2002.77.s-1.35 
DeFond, M. L., \& Jiambalvo, J. (1991). Incidence and circumstances of accounting errors. Accounting review, 643-655.

Deloitte. (2005). Differences between NZ Equivalents to IFRS and current NZ GAAP. Retrieved from http://www.iasplus.com/en/binary/nz/2005nzifrsnzgaap.pdf

External Reporting Board of New Zealand. (2007). New Zealand Equivalent to International Accounting

Standard 1 Current/non-current distinction (Vol. 1). New Zealand.

External Reporting Board of New Zealand. (2016). Accounting Standards Framework. Retrieved from file://C:/Users/OEM/Downloads/Approved\%20Accounting\%20Standards\%20Framewor k\%20(incl\%20Tier\%20Strategy).pdf

Gernon, H. M., Purvis, S., \& Diamond, M. A. (1990). An Analysis of the Implications of the IASC's Comparability Project: School of Accounting, University of Southern California.

Griffin, P. A., Lont, D. H., \& Sun, Y. (2009). Governance regulatory changes, International Financial Reporting Standards adoption, and New Zealand audit and non-audit fees: empirical evidence. Accounting \& Finance, 49(4), 697-724. https://doi.org/10.1111/j.1467-629X.2009.00310.x

Khan, S., Anderson, M., Warsame, H., \& Wright, M. (2015). Do IFRS-Based Earnings Announcements Have More Information Content than Canadian GAAP-Based Earnings Announcements? Accounting Perspectives, 14(3), 276-302. https://doi.org/10.1111/1911-3838.12052

Lim, C. Y., Lim, C. Y., \& Lobo, G. J. (2013). IAS 39 reclassification choice and analyst earnings forecast properties. Journal of accounting and public policy, 32(5), 342-356. https://doi.org/10.1016/j.jaccpubpol.2013.06.006

Misirlioglu, I. U., Tucker, J., \& Yükseltürk, O. (2013). Does Mandatory Adoption of IFRS Guarantee Compliance. The International Journal of Accounting, 48(3), 327. https://doi.org/10.1016/j.intacc.2013.07.002

Nichols, N. B., Street, D. L., \& Cereola, S. J. (2012). An analysis of the impact of adopting IFRS 8 on the segment disclosures of European blue chip companies. Journal of International Accounting, Auditing and Taxation, 21(2), 79-105. https://doi.org/10.1016/j.intaccaudtax.2012.07.001

Oliver, C. (1991). Strategic Responses to Institutional Processes. The Academy of Management Review, 16(1), 145-179. doi:10.2307/258610. https://doi.org/10.2307/258610

Onali, E., \& Ginesti, G. (2014). Pre-adoption market reaction to IFRS 9: A cross-country eventstudy. Journal of accounting and public policy, 33(6), 628-637. https://doi.org/10.1016/i.jaccpubpol.2014.08.004

Perumpral, S. E., Evans, M., Agarwal, S., \& Amenkhienan, F. (2009). The evolution of Indian accounting standards: Its history and current status with regard to International Financial Reporting Standards. Advances in Accounting, 25(1), 106-111. https://doi.org/10.1016/.adiac.2009.02.003

Pran, K. B. (2006). Measuring De jure Harmonisation: A Content Analysis of the Accounting Standards of three countries: South Africa, Mauritius and Tanzanian and International Financial Reporting Standards. Journal of Applied Accounting Research, 8(2), 110-146. https://doi.org/10.1108/96754260680001051

Salman, F. M., \& Carson, E. (2009). The Impact of the Sarbanes-Oxley Act on the Audit Fees of Australian Listed Firms. International Journal of Auditing, 13(2), 127-140. 
https://doi.org/10.1111/j.1099-1123.2009.00399.x

Samujh, H. (2007). IFRS for SMEs: a New Zealand perspective.

Schaltegger, S., \& Burritt, R. L. (2010). Sustainability accounting for companies: Catchphrase or decision support for business leaders? Journal of World Business, 45(4), 375-384. https://doi.org/10.1016/j.jwb.2009.08.002

Sunder, S. (2009). IFRS and the Accounting Consensus. Accounting Horizons, 23(1), 101-111. https://doi.org/10.2308/acch.2009.23.1.101

The New Zealand Treasury. (2007). Government's transition to New Zealand equivalents to International Financial

$\begin{array}{lllll}\text { Reporting } & \text { Standards } & \text { (NZ } & \text { IFRS) } & \text { Retrieved }\end{array}$ http://www.treasury.govt.nz/publications/guidance

White, W., \& Ryan, A. (2007). Transition to NZ equivalents to International Financial Reporting Standards. Retrieved from http://www.treasury.govt.nz/publications/guidance/reporting

Zijl, T., \& Bradbury, M., E. (2006). Due process and the adoption of IFRS in New Zealand. Australian accounting review, 16(39), 86-94.

https://doi.org/10.1111/j.1835-2561.2006.tb00363.x 


\section{Appendix 1.}

\section{Corporate Entity Register Statistics}

\begin{tabular}{|c|c|c|c|c|}
\hline Register & $\begin{array}{l}\text { New registrations } \\
\text { in } 2012-2013\end{array}$ & $\begin{array}{l}\text { New registrations } \\
\text { in 2013-2014 }\end{array}$ & $\begin{array}{l}\text { New registrations } \\
\text { in } 2014-2015\end{array}$ & $\begin{array}{l}\text { Total registered as } \\
\text { at } 30 \text { June } 2015\end{array}$ \\
\hline & & & & as at 30 June 2015 \\
\hline Building Societies & 2 & 1 & 0 & 10 \\
\hline Charitable Trusts & 756 & 788 & 866 & 23,009 \\
\hline $\begin{array}{l}\text { Contributory } \\
\text { Mortgage Brokers }\end{array}$ & 0 & 1 & 0 & 12 \\
\hline Credit Unions & 0 & 0 & 0 & 19 \\
\hline Friendly Societies & 0 & 0 & 1 & 135 \\
\hline $\begin{array}{l}\text { Incorporated } \\
\text { Societies }\end{array}$ & 805 & 734 & 705 & 23,572 \\
\hline $\begin{array}{ll}\text { Industrial } & \text { and } \\
\text { Provident } & \end{array}$ & 3 & 3 & 0 & 82 \\
\hline $\begin{array}{l}\text { Limited } \\
\text { Partnerships (NZ) }\end{array}$ & 337 & 292 & 379 & 2,018 \\
\hline $\begin{array}{l}\text { Limited } \\
\text { Partnerships } \\
\text { (Overseas) }\end{array}$ & 7 & 1 & 1 & 13 \\
\hline NZ Co-operatives & 12 & 8 & 10 & 108 \\
\hline $\begin{array}{l}\text { NZ Limited } \\
\text { Companies }\end{array}$ & 43,999 & 47,215 & 50,419 & 550,855 \\
\hline $\begin{array}{l}\text { NZ Unlimited } \\
\text { Companies }\end{array}$ & 34 & 35 & 36 & 371 \\
\hline $\begin{array}{ll}\text { Overseas } & \text { ASIC } \\
\text { Companies } & \end{array}$ & 194 & 152 & 208 & 1,275 \\
\hline Overseas Issuers & 92 & 92 & 113 & 1,067 \\
\hline $\begin{array}{l}\text { Overseas NON- } \\
\text { ASIC Companies }\end{array}$ & 99 & 68 & 106 & 566 \\
\hline $\begin{array}{l}\text { Retirement } \\
\text { Villages }\end{array}$ & 14 & 147 & 19 & 383 \\
\hline Securities Act & 23 & 48 & 29 & 354 \\
\hline $\begin{array}{l}\text { Superannuation } \\
\text { Schemes }\end{array}$ & 5 & 3 & 1 & 243 \\
\hline Unit Trusts & 18 & 24 & 21 & 368 \\
\hline Total & 46,400 & 49,612 & 52,914 & 604,460 \\
\hline
\end{tabular}

